\title{
Cellulase and Xylanase Production by Yeasts of the Genus Trichosporon
}

\author{
By B. J. H. STEVENS AND J. PAYNE \\ Agricultural Research Council Food Research Institute, Colney Lane, \\ Norwich NR4 7 UA
}

(Received 21 December 1976)

\section{SUMMARY}

The optimum conditions for cellulase production in culture filtrates by Trichosporon cutaneum and T. pullulans were determined. With ball-milled filter paper as a test substrate maximum activity was detected 4 to 7 days after transfer from glucose to cellulose (ball-milled filter paper) as growth substrate. Comparison of the yeast filtrates with those from the moulds Trichoderma viride and Myrothecium verrucaria showed that the total activity of one strain of $T$. pullulans was comparable to that of the moulds with ball-milled filter paper as assay substrate. Activities were always lower when $\alpha$-cellulose or dewaxed cotton were used as assay substrates. The main products of cellulose degradation were cellobiose and glucose, although the ratio of these products clearly differentiated between culture filtrates of the species examined. Xylanase activity was present in all the culture filtrates examined. Polyacrylamide gel electrophoresis of active filtrates produced strainspecific patterns of three to five stained bands with similar mobilities but an inactive filtrate lacked one band common to all the other filtrates.

\section{INTRODUCTION}

Cellulase enzymes from the moulds Trichoderma viride, Myrothecium verrucaria and Aspergillus niger are widely used for food processing (Mandels \& Weber, I969; Toyama, I969; Pathak \& Ghose, 1973 $a, b$ ) but a search for more active preparations has continued (Wood \& Phillips, 1969; Mandels, Weber \& Parizek, 197I). Cellulase activity has been reported in cultures of the yeasts Trichosporon cutaneum and Trichosporon pullulans by Dennis (1972). This paper investigates the effect of growth conditions on cellulase production in these yeasts and compares the activity with that produced by the moulds Trichoderma viride and Myrothecium verrucaria. In addition, the detection of xylose in some assay filtrates led to the discovery of xylanase activity in all the strains examined.

\section{METHODS}

Organisms and maintenance of stock cultures. Trichosporon pullulans strains CBS2532, CBS2533, CBS2536 and CBS2543 were obtained from Centraalbureau voor Schimmelcultures, Baarn, Holland: T. pullulans strain c35, and strains of Trichosporon cutaneum and Trichoderma viride were isolated locally (Dennis, 1972; Dennis \& Gee, 1973). Myrothecium verrusaria strain IMI4554I was obtained from the Commonwealth Mycological Institute, Kew, Surrey. Yeasts were subcultured every 6 weeks at $20^{\circ} \mathrm{C}$ and stored at $2{ }^{\circ} \mathrm{C}$ on Difco YM agar slants, $\mathrm{pH} 6 \cdot 2$. The moulds were grown similarly and maintained on $2 \%(\mathrm{w} / \mathrm{v})$ Difco malt extract agar.

Growth of cultures for cellulase assay. Cultures in 50 or $100 \mathrm{ml}$ medium, unless otherwise 
stated, were grown in 250 or $1000 \mathrm{ml}$ conical flasks, respectively, on a gyratory shaker at Ioo rev. $\min ^{-1}$ at $20^{\circ} \mathrm{C}$. They were inoculated with yeast cultures, grown on Difco YM slants for 3 days at $20^{\circ} \mathrm{C}$, to give $\mathrm{I} \times 10^{7}$ cells ml-1, or with mould cultures, grown on Difco malt extract agar, to give $3 \times 10^{5}$ spores $\mathrm{ml}^{-1}$.

Media used were (i) the glucose medium of Wickerham \& Burton (I948), as modified by Barnett \& Ingram (I955), with $0.025 \mathrm{M}$-glucose, and (ii) a cellulose medium, based on medium I of Bravery (I968), which contained (g 1-1): $\mathrm{KH}_{2} \mathrm{PO}_{4}, 5 \cdot 0 ; \mathrm{MgSO}_{4} \cdot 7 \mathrm{H}_{2} \mathrm{O}, 0 \cdot 5$; $\mathrm{CaCl}_{2}, 0 . \mathrm{I} ; \mathrm{NH}_{4} \mathrm{Cl}, 2.5 ;$ DL-asparagine, 0.5 ; and Difco yeast extract, 0.5 . The latter medium was sterilized by autoclaving at $\mathrm{I} 2 \mathrm{I}{ }^{\circ} \mathrm{C}$ for $\mathrm{I} 5 \mathrm{~min}$. Where cellulose was the growth substrate, a $2 \%(w / v)$ suspension of ball-milled filter paper in distilled water was added, after autoclaving separately, to give a final concentration of $0.5 \%(w / v)$. Larchwood xylan was added in a similar way where stated.

For experiments in which the medium was buffered, the $\mathrm{pH}$ of the basal medium was adjusted to the required value and a filter-sterilized solution of the appropriate buffer was added to a final concentration of $0.05 \mathrm{M}$. Buffers were potassium hydrogen phthalate/ $\mathrm{NaOH}$ for $\mathrm{pH}_{3}, 4$ and $4 \cdot 8$ and potassium phosphate for $\mathrm{pH} 6$ and 7 .

Glucose-grown cultures were transferred to cellulose medium either when the glucose concentration fell below $0.05 \%(\mathrm{w} / \mathrm{v})$ or when it stopped decreasing, as determined by the oxidase method (GOD-Perid, Boehringer). Most yeast cultures completely utilized the glucose in 2 days, but moulds required 3 or 4 days. Yeast cultures were harvested aseptically by centrifuging $\left(2000 \mathrm{~g}, 15 \mathrm{~min}, 20^{\circ} \mathrm{C}\right)$ and the cells were resuspended in a volume of sterile basal cellulose medium equal to the culture volume, centrifuged again and finally suspended in the required volume of sterile distilled water for addition to the medium containing cellulose. The effects of temperature and $\mathrm{pH}$ on cellulase production by $T$. cutaneum YI and T. pullulans $\mathrm{C}_{3} 5$ were examined in 11 glucose-limited chemostat cultures growing at dilution rates of $0.23 \mathrm{~h}^{-1}$ and $0.10 \mathrm{~h}^{-1}$ respectively in a Porton-type chemostat (Evans, Herbert \& Tempest, 1970). Mould mycelium was removed from the glucose medium by filtration through a sterile sintered glass filter (no. I or no. 2 porosity), washed on the filter with sterile basal cellulose medium and suspended in sterile distilled water before addition to the cellulose medium. If large pellets had formed, they were macerated in sterile distilled water in $25 \mathrm{ml}$ homogenizer bottles with an MSE homogenizer.

Growth could not be followed turbidimetrically due to the nature of the substrates. With yeast cultures direct microscopic counts under phase contrast were made in a Thoma counting chamber. No attempt was made to follow the growth of mould cultures: these were usually harvested after 5 days incubation in cellulose medium. If good growth was not apparent after this time, as judged visually, then cultures were incubated for a further 2 days.

Culture filtrates and enzyme assays. Yeast cultures were centrifuged and successively filtered through Millipore membrane filters (pore sizes $0.8 \mu \mathrm{m}$ and $0.45 \mu \mathrm{m}$, type MF, mixed cellulose esters) to remove cells. Mould cultures were first filtered through sintered glass filters (porosity 3 ) and then successively through membrane filters as above, but including one with a pore size of $0.22 \mu \mathrm{m}$ to remove spores. The filtrates were used as the source of enzymes; they were stored at $2{ }^{\circ} \mathrm{C}$ after addition of $\mathrm{NaN}_{3}$ to a concentration of 0.005 M (Selby, 1967).

Cellulase activity was assayed by a method similar to that of Halliwell (I96I) but modified on the basis of preliminary experiments which showed that the reaction rate was linear up to Io $\mu \mathrm{g}$ protein $\mathrm{ml}^{-1}$ for $3.5 \mathrm{~h}$, and the $\mathrm{pH}$ optimum was between 3.5 and 4.5 . Incubation mixtures contained (in a final volume of $4 \mathrm{ml}$ ): substrate (ball-milled filter paper, $\alpha$-cellulose or dewaxed cotton), $20 \mathrm{mg} ; 0.2 \mathrm{M}$-sodium acetate buffer $\mathrm{pH} 4.5, \mathrm{I} \cdot 3 \mathrm{ml}$; and culture filtrate 
containing not more than $40 \mu \mathrm{g}$ soluble protein. Incubation was normally for $3 \mathrm{~h}$ at $37^{\circ} \mathrm{C}$ but when longer times were used $0.02 \mathrm{ml}$ of I M-NaN $\mathrm{N}_{3}$ was added as a preservative. In controls, $0.5 \mathrm{ml}$ of $0.3 \mathrm{M}-\mathrm{H}_{2} \mathrm{SO}_{4}$ was added before the enzyme. Cellulolysis was measured by the increase in soluble carbohydrate formed, expressed as glucose, estimated by the reduction of dichromate (Halliwell, 1960) which was followed spectrophotometrically at $440 \mathrm{~nm}$. For low levels of soluble carbohydrate, the dichromate concentration was reduced from $0.25 \%(\mathrm{w} / \mathrm{v})$ to $0.15 \%(\mathrm{w} / \mathrm{v})$ in $96 \%(\mathrm{w} / \mathrm{v}) \mathrm{H}_{2} \mathrm{SO}_{4}$; with glucose as a standard this gave a linear response over the range 50 to $400 \mu \mathrm{g} \mathrm{ml}^{-1}$. Cellulase activity was expressed in units $(\mu \mathrm{g} \text { protein })^{-1}$; I unit produced $\mathrm{I} \mu \mathrm{g}$ soluble carbohydrate $\mathrm{h}^{-1}$, expressed as glucose. A similar method was used to assay xylanase activity except that the substrate was $20 \mathrm{mg}$ powdered xylan and controls contained culture filtrate which had been heated at $100{ }^{\circ} \mathrm{C}$ for $\mathrm{I} 5 \mathrm{~min}$.

Analytical methods. Products of cellulolysis were identified in samples (Io to $20 \mu \mathrm{l}$ ) of the assay filtrates by thin layer chromatography (t.l.c.) using (i) $0.5 \mathrm{~mm}$ layers of silica gel $\mathrm{G}$ (Merck) with a double development to $\mathrm{I} 5 \mathrm{~cm}$ from the origin in ethyl acetate/propan-2-ol/ water (20:13:7, by vol.) (Brown, 1970) and (ii) $0.25 \mathrm{~mm}$ layers of cellulose with double development in butan-I-ol/pyridine/water ( $6: 4: 3$, by vol.). Reducing sugars and oligosaccharides were detected by spraying with aniline phosphate and heating for $20 \mathrm{~min}$ at $115^{\circ} \mathrm{C}$ (Frahn \& Mills, 1959). Glucose and cello-oligosaccharides appeared as brown spots but their yellow fluorescence under ultraviolet light [Mineralight (UVSL-58) Ultra-violet Products, California, U.S.A.] provided a more sensitive method of detection. Solutions of individual cellooligosaccharides from cellotriose to celloheptaose were prepared from partially hydrolysed Whatman grade $\mathrm{CC}_{4} \mathrm{I}$ cellulose powder by the method of Miller (1963). Since the presence of $\mathrm{H}_{2} \mathrm{SO}_{4}$ and acetic acid in the assay filtrates affected the migration of the components, a mixture of the standard carbohydrates was prepared in $\mathrm{H}_{2} \mathrm{SO}_{4}$ /acetic acid of the same composition. Migration distances of unknown compounds were measured relative to glucose in this mixture and expressed as $R_{\text {Glc }}$ values.

For the detection of products of xylan hydrolysis, aniline phthalate was preferred; aldopentoses gave red or pink spots, aldohexoses green/brown (Partridge, 1949). Xylobiose and xylotriose were tentatively identified by their pink colours and their migration distances relative to xylose $\left(R_{\mathrm{x} \mathbf{y}}\right)$ compared with glucose, cellobiose and cellotriose. With system (i), $R_{\mathrm{Xy} 1}$ values were: glucose $0.8 \mathrm{I}$, cellobiose 0.55 , presumed xylobiose $0.7 \mathrm{I}$, cellotriose 0.37 , presumed xylotriose 0.48 . Galactose, arabinose and mannose were included as markers when the presence of these compounds was suspected. System (ii) gave a better separation of glucose, mannose and galactose.

Cellobiose in assay filtrates was estimated enzymically as glucose after enzymic hydrolysis by a $\beta$-glucosidase preparation as follows. Tubes containing $0 . \mathrm{I}$ to $0.4 \mathrm{ml}$ of the assay filtrate, $0.05 \mathrm{ml}$ of I $\mathrm{M}$-acetate buffer $\mathrm{pH} 5.0$, and $0.05 \mathrm{ml} \beta$-glucosidase (emulsion from almonds, Sigma) in $0.02 \mathrm{M}$-acetate buffer $\mathrm{pH} 5.0$ were incubated for $3 \mathrm{~h}$ at $37^{\circ} \mathrm{C}$. Since some of the assay filtrates contained glucose initially, duplicate estimations were made without $\beta$-glucosidase. Controls with no substrate and cellobiose standards were also included and results were calculated by subtracting the control figures. After incubation, samples $(0 \cdot$ I to $0.2 \mathrm{ml}$ ) were taken for estimation of glucose by measuring the NADPH formed by the action of hexokinase and glucose-6-phosphate dehydrogenase in the presence of NADP at $30{ }^{\circ} \mathrm{C}$. The assay system contained (in a final volume of $1.2 \mathrm{ml}$ ): I M-Tris buffer $\mathrm{pH} 8 \cdot 0$, $0.2 \mathrm{ml}$; NADP (4 mg ml-1), $0.05 \mathrm{ml}$; 0.I M-ATP, $0.05 \mathrm{ml} ; 0 . \mathrm{I} \mathrm{M}-\mathrm{MgCl}_{2} .6 \mathrm{H}_{2} \mathrm{O}, 0.05 \mathrm{ml}$; and hexokinase/glucose-6-phosphate dehydrogenase $\left(3 \mathrm{mg} \mathrm{ml}^{-1}\right)$, 0.0 I $\mathrm{ml}$. After equilibration the reaction was started by adding the glucose-containing sample and the increase in $E_{340}$ was followed spectrophotometrically to completion. ATP disodium salt, NADP disodium salt 
and hexokinase/glucose-6-phosphate dehydrogenase suspensions were obtained from Boehringer.

Polyacrylamide gel electrophoresis. Culture filtrates were concentrated Io-fold by ultrafiltration through Sartorius collodion membranes against $0.02 \mathrm{M}$-acetate buffer $\mathrm{pH} 4.5$. Disc gel electrophoresis was based on the method of Davis \& Ornstein (I96I) at pH 8.9 with $7 \%(\mathrm{w} / \mathrm{v}$ ) acrylamide. Samples ( $0 . \mathrm{I}$ to $0.2 \mathrm{ml}$, about $\mathrm{I} 40 \mu \mathrm{g}$ protein) were layered on to gels and $0.05 \mathrm{ml}$ bromophenol blue $(0.001 \%$ w/v) was added to each. Electrophoresis was carried out at $2{ }^{\circ} \mathrm{C}$ with a current of I $\mathrm{mA}$ per tube until the bromophenol blue had migrated into the gel; the current was then increased to $3 \mathrm{~mA}$ per tube. Gels were stained with $\mathrm{I} \%(\mathrm{w} / \mathrm{v})$ amido black in $7 \%(\mathrm{v} / \mathrm{v})$ acetic acid; and destained by washing repeatedly with $7 \%$ acetic acid. Densitometer profiles of the stained gels were recorded with a Chromoscan (Joyce-Loebl, Gateshead, Tyne \& Wear).

Determination of protein. The method of Lowry et al. (I95I) was used, after dialysis against distilled water for $24 \mathrm{~h}$ at $2{ }^{\circ} \mathrm{C}$; crystalline bovine serum albumin (Armour Pharmaceutical Co., Eastbourne, Sussex) was used as a standard.

Preparation of cellulose and xylan substrates. Ball-milled filter paper was prepared as follows: I2 $\mathrm{g}$ Whatman no. I filter paper was cut into small pieces, mixed with $300 \mathrm{ml}$ distilled water and ball-milled in a 11 porcelain pot for 4 days at $2{ }^{\circ} \mathrm{C}$ (model 9; Pascall Engineering, Crawley, Sussex). The cellulose suspension formed was diluted with distilled water to give a $2 \%(\mathrm{w} / \mathrm{v})$ suspension, and this was stored at $2{ }^{\circ} \mathrm{C}$. Dewaxed cotton yarn was kindly given by Scandura, Cleckheaton, Yorkshire, and was of the type used for conveyor belt carcasses (Walsh \& Stewart, 197I). It was cut into short pieces and partially untwisted before being dewaxed by the method of Halliwell (1957). $\alpha$-Cellulose, unless stated otherwise, was $\alpha$-cellulose fibre (approximately $99.5 \%$; Sigma) used without further treatment. For some experiments Whatman cellulose powder types CFI (long fibre length) and CFI I (medium fibre length) were used. Larchwood xylan was purified by a method based on that of Aspinall \& McKay (I958). Commercial powdered xylan (Sigma) was extracted with water for $\mathrm{I} 8 \mathrm{~h}$ at $2{ }^{\circ} \mathrm{C}$, and the residue was then extracted successively, at room temperature, with $\mathrm{I} \%(\mathrm{w} / \mathrm{v}) \mathrm{NaOH}$ and $4 \%(\mathrm{w} / \mathrm{v}) \mathrm{NaOH}$ (oxygen free). Fractions were precipitated from the alkali extracts by acidification to $\mathrm{pH}_{4}$ with glacial acetic acid and then by addition of acetone to the acidified supernatant fluid. Precipitates were washed with ethanol and dried

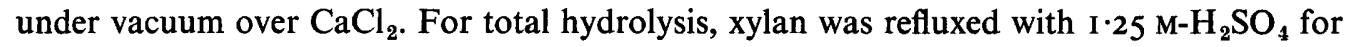
$5 \mathrm{~h}$, cooled and the $\mathrm{pH}$ was adjusted to 6 by adding saturated $\mathrm{Ba}(\mathrm{OH})_{2}$ solution. After filtration, $\mathrm{Ba}^{2+}$ ions were removed by passage through a cation exchange resin (BioRad $\left.\mathrm{AG}_{50} \times 8\right)$ and the hydrolysate was then concentrated to a small volume for chromatography.

\section{RESULTS}

\section{Growth of organisms and cellulase production}

Growth of Trichosporon cutaneum Y I in ball-milled filter paper medium was slow. It was not possible to separate cells from cellulose fibres by filtration so growth was measured by direct microscopic counts, although the presence of budding and filamentous cells sometimes made this difficult. With an inoculum of about $6.3 \times 10^{6}$ cells $\mathrm{ml}^{-1}$, cellulase activity, assayed with ball-milled filter paper as substrate, appeared after 9 days at $20^{\circ} \mathrm{C}$ when the cell count approached $10^{9}$ cells $\mathrm{ml}^{-1}$ (Fig. I). The addition of $0.05 \%(\mathrm{w} / \mathrm{v})$ cellobiose or glucose to the cellulose medium did not stimulate cellulase production. A higher concentration of glucose, while producing rapid growth and supernatant protein concentrations of about $100 \mu \mathrm{g} \mathrm{ml}^{-1}$, repressed cellulase synthesis completely. When $T$. cutaneum 


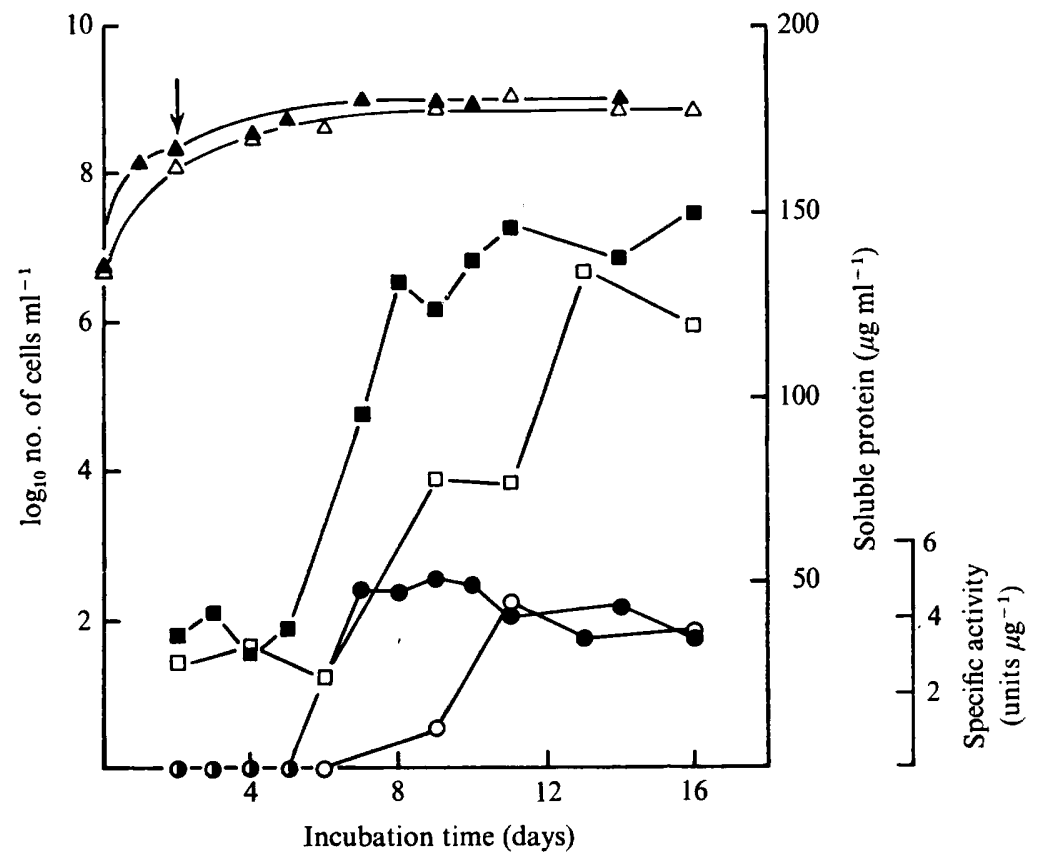

Fig. I. Total cell count, protein and cellulase production by Trichosporon cutaneum YI. Cultures were grown at $20^{\circ} \mathrm{C}$ either on glucose medium for 2 days before transferring $(\downarrow)$ to ball-milled filter paper medium (filled symbols), or on ball-milled filter paper medium alone (open symbols). Cellulase activity with ball-milled filter paper as substrate $(0,0)$; soluble protein in culture filtrates $(\boldsymbol{a}, \square)$; and total cell count $(\boldsymbol{\Delta}, \triangle)$.

\section{Table I. Effect of growth temperature on cellulase production}

Cells from glucose-limited chemostat cultures were inoculated into ball-milled filter paper medium and grown at the stated temperature for 4 or 10 days. Cellulase activity was determined with ball-milled filter paper as substrate in $3 \mathrm{~h}$ incubations at $37^{\circ} \mathrm{C}$. I unit produces $\mathrm{I} \mu \mathrm{g}$ soluble carbohydrate $\mathrm{h}^{-1}$.

Trichosporon cutaneum $\mathrm{YI}$

Total activity [units $\mathrm{ml}^{-1}$ ]

Protein $\left[\mu \mathrm{g} \mathrm{ml}^{-1}\right]$

Specific activity [units

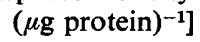

Trichosporon pullulans $\mathrm{C}_{3} 5$

Total activity [units $\mathrm{ml}^{-1}$ ]

Protein $\left[\mu \mathrm{g} \mathrm{ml}^{-1}\right]$

Specific activity [units ${\left.\text { ( } \mu \text { g protein })^{-1}\right]}$

\begin{tabular}{rrrrrrrrrr}
\multicolumn{4}{c}{ Incubated for 4 days at: } & \multicolumn{5}{c}{ Incubated for ro days at: } \\
$\overbrace{10{ }^{\circ} \mathrm{C}}$ & $15{ }^{\circ} \mathrm{C}$ & $20{ }^{\circ} \mathrm{C}$ & $25{ }^{\circ} \mathrm{C}$ & $30{ }^{\circ} \mathrm{C}$ & $\overbrace{10{ }^{\circ} \mathrm{C}}$ & $15{ }^{\circ} \mathrm{C}$ & $20{ }^{\circ} \mathrm{C}$ & $25{ }^{\circ} \mathrm{C}$ & $30{ }^{\circ} \mathrm{C}$ \\
0 & 15 & 0 & 1104 & 19 & 0 & 97 & 1492 & 1815 & 165 \\
50 & 50 & 58 & $18 \mathrm{I}$ & 63 & $5 \mathrm{I}$ & 69 & 297 & 288 & 127 \\
0 & 0.3 & 0 & $6 . \mathrm{I}$ & 0.3 & 0 & $1 \cdot 4$ & 5.2 & 6.3 & $1 \cdot 3$ \\
& & & & & & & & & \\
0 & 19 & 1404 & 1125 & 0 & 48 & 1134 & 1554 & 1391 & 64 \\
29 & 31 & 216 & 148 & 14 & 40 & 189 & 222 & 196 & 46 \\
0 & 0.6 & 6.5 & 7.6 & 0 & $1 \cdot 2$ & 6.0 & 7.0 & 7.1 & $1 \cdot 4$
\end{tabular}

Y I was grown in glucose medium until no glucose was detected in the supernatant fluid and then transferred to ball-milled filter paper medium, supernatant protein and cellulase activity were detected 2 to 3 days earlier than when it was grown in ball-milled filter paper medium alone (Fig. I). This two-stage growth procedure was subsequently used routinely.

A comparison of cellulase production at different growth temperatures showed that activity was detected after 4 days when $T$. cutaneum Y I was grown at $25^{\circ} \mathrm{C}$, but after Io days the specific activity had not increased and was not significantly higher than at $20^{\circ} \mathrm{C}$ (Table $\mathrm{I}$ ). 


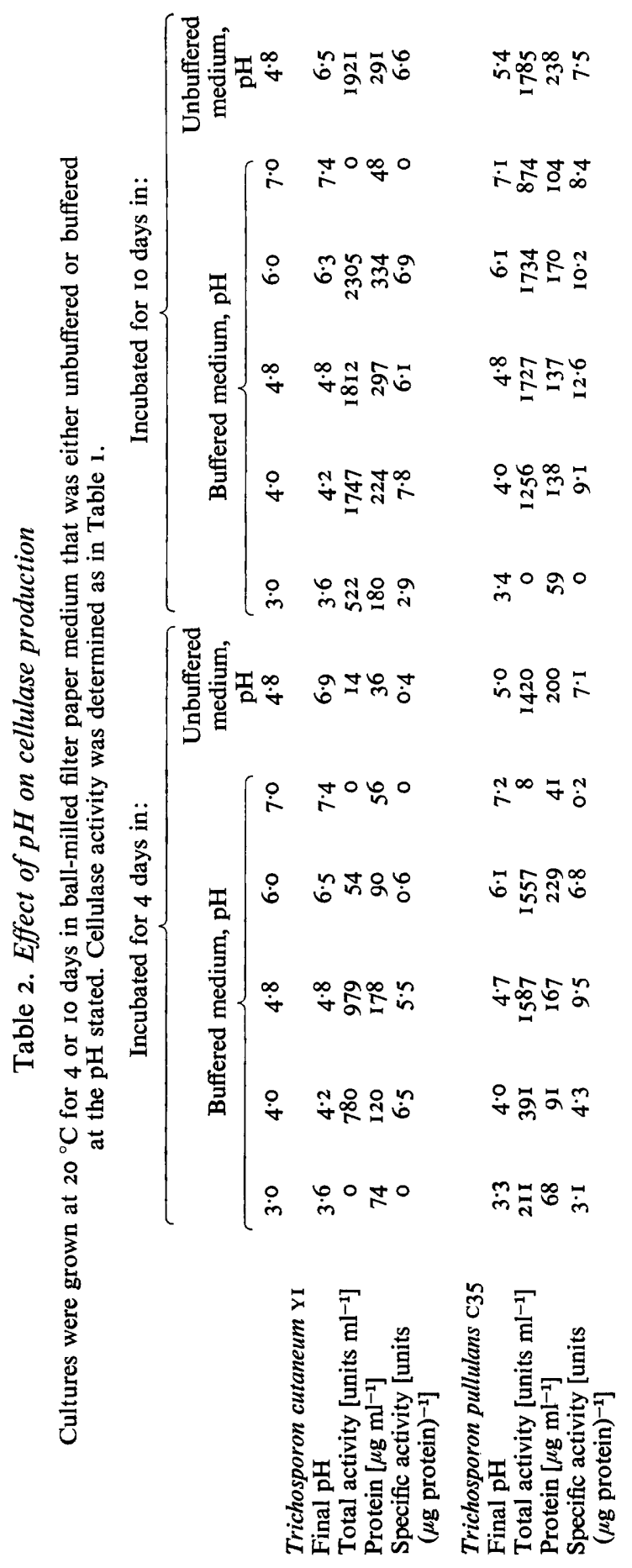


Table 3. Cellulase production by yeasts and moulds

Glucose-grown batch cultures were transferred to ball-milled filter paper medium and incubated at $20^{\circ} \mathrm{C}$. Cellulase activity was determined as in Table $\mathrm{I}$.

\begin{tabular}{|c|c|c|c|c|}
\hline Organism & $\begin{array}{l}\text { Time in } \\
\text { cellulose } \\
\text { medium } \\
\text { (days) }\end{array}$ & $\begin{array}{l}\text { Total activity } \\
\text { in filtrate } \\
\text { (units } \mathrm{ml}^{-1} \text { ) }\end{array}$ & $\begin{array}{l}\text { Protein in } \\
\text { filtrate } \\
\left(\mu \mathrm{g} \mathrm{ml}^{-1}\right)\end{array}$ & $\begin{array}{c}\text { Specific } \\
\text { activity [units } \\
(\mu \mathrm{g} \text { protein })^{-1} \text { ] }\end{array}$ \\
\hline Trichosporon cutaneum $\mathrm{G} 3 \mathrm{I}$ & 7 & 950 & 120 & $7 \cdot 9$ \\
\hline$T$. cutaneum GI & 7 & 674 & 9I & $7 \cdot 4$ \\
\hline T. cutaneum GI 24 & 7 & 440 & 88 & $5 \cdot 0$ \\
\hline T. cutaneum YI & 5 & 513 & 107 & $4 \cdot 8$ \\
\hline T. cutaneum GI 42 & 7 & 194 & 57 & $3 \cdot 4$ \\
\hline T. cutaneum RHY59 & 7 & 68 & 34 & $2 \cdot 0$ \\
\hline T. cutaneum Y 6 & 7 & 65 & 50 & I·3 \\
\hline$T$. cutaneum YI 2 & 7 & $6 I$ & $6 I$ & $I \cdot 0$ \\
\hline T. pullulans $\mathrm{CBS} 2532$ & 7 & 1900 & 190 & $10 \cdot 0$ \\
\hline$T$. pullulans $\mathrm{C} 35$ & 7 & 2060 & 258 & $8 \cdot 0$ \\
\hline T. pullulans CBS2533 & 7 & 330 & 103 & $3 \cdot 2$ \\
\hline T. pullulans CBS2536 & 7 & 96 & 64 & $I \cdot 5$ \\
\hline T. pullulans CBS 2543 & 7 & 52 & 35 & $1 \cdot 5$ \\
\hline Trichoderma viride CSI 32 & 5 & 213 I & 132 & $16 \cdot 1$ \\
\hline Trichoderma viride $\operatorname{csI} 2$ & 9 & 2796 & 229 & $13 \cdot 0$ \\
\hline Trichoderma viride CSI 2 & 7 & 2760 & 214 & $12 \cdot 9$ \\
\hline Myrothecium verrucaria IMI4554 I & 5 & 2560 & 264 & $9 \cdot 7$ \\
\hline
\end{tabular}

With $T$. pullulans $\mathrm{C} 35$ the specific activities after 4 days growth at 20 and $25^{\circ} \mathrm{C}$ were comparable and about the same after Io days. At $15{ }^{\circ} \mathrm{C}$ little cellulase activity was detected after 4 days but by 10 days the specific activity was similar to that at 20 and $25^{\circ} \mathrm{C}$.

During routine screening of strains for cellulase activity we found that the $\mathrm{pH}$ rose if the growth medium was not buffered. Use of media buffered at different $\mathrm{pH}$ values showed that cellulase production by $T$. pullulans $\mathrm{C} 35$ was favoured by a slightly more alkaline pH than that by $T$. cutaneum YI (Table 2 ).

\section{Cellulase production by different strains}

With ball-milled filter paper as assay substrate, eight strains of T. cutaneum and five of $T$. pullulans showed specific cellulase activities of at least $\mathrm{I} \cdot \mathrm{O}$ (Table 3 ). The published data for mould cellulases did not allow direct comparison with our results so two strains of Trichoderma viride and one of Myrothecium verrucaria were grown and assayed for cellulase activity under our conditions (i.e. with ball-milled filter paper as both growth and assay substrate). The specific activities of the mould cellulases were two- to three-fold higher than those of the most active Trichosporon spp. (Table 3) but the total cellulase activity from T. pullulans $\mathrm{C} 35$ was comparable to those from the moulds. Trichosporon pullulans CBS2532 and $\mathrm{C}_{35}$ and $T$. cutaneum YI, GI and G3I were selected for further study together with one strain each of Trichoderma viride and $M$. verrucaria.

\section{Cellulase activity with other assay substrates}

With less-degraded forms of cellulose, $\alpha$-cellulose and dewaxed cotton yarn as substrates, specific activities were lower than with ball-milled filter paper (Table 4) and, of the yeast species, the cellulase preparation from $T$. pullulans $\mathrm{C} 35$ showed the highest activity in the standard assay time of $3 \mathrm{~h}$ (comparable to that from Trichoderma viride CSI2). If the assay 


\section{Table 4. Comparison of cellulase and xylanase activities}

Cultures were grown as in Table 3, and cellulase and xylanase activities were determined with ballmilled filter paper, $\alpha$-cellulose, dewaxed cotton or larchwood xylan as substrate in $3 \mathrm{~h}$ incubations at $37^{\circ} \mathrm{C}$. Additional data in parentheses is from $24 \mathrm{~h}$ incubations. Activities are expressed as units $(\mu \mathrm{g} \text { protein })^{-1}$.

Organism
cutaneum $\mathrm{YI}$
$\mathrm{YI}$
$\mathrm{GI}$
$\mathrm{CBS} 2532$
$\mathrm{CBS} 2532$
$\mathrm{C} 35$
$\mathrm{C} 35$
a viride CSI 2
a viride CSI 2
verrucaria $\mathrm{IMI} 4554 \mathrm{I}$
ia $\mathrm{IMI} 4554 \mathrm{I}$

$\begin{array}{cc}\begin{array}{c}\text { Time in } \\ \text { cellulose }\end{array} & \begin{array}{c}\text { Protein } \\ \text { medium } \\ \text { (days) }\end{array} \\ \begin{array}{c}\text { in filtrate } \\ \left(\mu \mathrm{g} \mathrm{m}^{-1}\right)\end{array} \\ 5 & 107 \\ \text { I0 } & \text { I } 54 \\ 7 & 9 \mathrm{I} \\ 7 & \text { I } 49 \\ 7 & 190 \\ 7 & 98 \\ 7 & 258 \\ \text { I I } & 73 \\ 7 & 2 \text { I } 4 \\ 9 & 229 \\ 5 & 264 \\ \text { I I } & \text { I35 } \\ \text { NT, Not tested. }\end{array}$

\begin{tabular}{|c|c|c|c|}
\hline \multicolumn{3}{|c|}{ Cellulase activity } & Xylanase \\
\hline $\begin{array}{c}\text { Ball- } \\
\text { milled } \\
\text { filter } \\
\text { paper }\end{array}$ & $\begin{array}{c}\alpha \text {-Cellu- } \\
\text { lose }\end{array}$ & $\begin{array}{c}\text { Dewaxed } \\
\text { cotton }\end{array}$ & $\begin{array}{l}\text { Larch- } \\
\text { wood } \\
\text { xylan }\end{array}$ \\
\hline $4 \cdot 8$ & $1 \cdot 9$ & $0.4(0.2)$ & NT \\
\hline $4 \cdot 2$ & NT & NT & $4 \cdot 0$ \\
\hline $7 \cdot 4$ & $I \cdot 5$ & 0 & NT \\
\hline $5 \cdot 4$ & NT & NT & 26 \\
\hline 10.0 & $I \cdot I$ & NT & NT \\
\hline $\begin{array}{l}9 \cdot 3 \\
8 \cdot 0\end{array}$ & $\begin{array}{l}\text { NT } \\
2 \cdot 6\end{array}$ & $\begin{array}{l}\text { NT } \\
0.9(0.4)\end{array}$ & $\begin{array}{l}72 \\
\text { NT }\end{array}$ \\
\hline $17 \cdot 9$ & NT & NT & 65 \\
\hline $12 \cdot 9$ & $3 \cdot 4$ & NT & 58 \\
\hline 13.0 & NT & $I \cdot 2(I \cdot I)$ & NT \\
\hline $9 \cdot 7$ & $1 \cdot 39$ & $2 \cdot 3(0.6)$ & NT \\
\hline $12 \cdot 3$ & NT & NT & $8 \cdot 4$ \\
\hline
\end{tabular}

time was extended to $24 \mathrm{~h}$, the specific activities on dewaxed cotton of filtrates from Trichosporon spp. and $M$. verrucaria were lower.

The inability of the preparation from $T$. cutaneum GI to degrade the dewaxed cotton and the low activity with $\alpha$-cellulose suggested that it could be deficient in one or more enzymes of the cellulase complex necessary for the initial attack on the highly ordered forms of cellulose in cotton fibre (Reese, Siu \& Levinson, I950). Since $M$. verrucaria filtrates appeared to possess this component and the yeast preparations appeared to possess high activity with less-polymerized forms of cellulose, filtrates were combined to look for synergistic effects. Equal units of $T$. cutaneum GI, $M$. verrucaria IMI4554I and Trichoderma viride CSI 2 enzymes were assayed for $3 \mathrm{~h}$ with $\alpha$-cellulose as substrate, singly, in pairs and all three together but no synergism was observed.

\section{Xylanase activity}

Examination of filtrates from a 7-day assay of Trichoderma viride cellulase with $\alpha$-cellulose as substrate showed the presence of appreciable amounts of an unidentified compound $\left(R_{\text {Glc }} I \cdot 23\right)$ which was not produced from other cellulose substrates. Total hydrolysis of the $\alpha$-cellulose followed by paper chromatography showed xylose to be present, possibly accounting for about $5 \%$ of the total carbohydrate. Further examination of the assay filtrates by t.l.c., with xylose added to the cello-oligosaccharide standard mixture, indicated that the unidentified compound was xylose. Accordingly the xylanase activity of culture filtrates was determined with larchwood xylan as substrate. The activities of four yeast strains were compared with the moulds Trichoderma viride and $M$. verrucaria which are known to produce xylanase (Bishop \& Whitaker, I955; Gascoigne \& Gascoigne, 1960). The total soluble carbohydrate produced in the assay system may have contained breakdown products of glucomannan present in the xylan preparation (Aspinall \& McKay, 1958). Filtrates from yeasts grown in the ball-milled filter paper medium had xylanase activities up to eight times higher than their cellulase activities (Table 4). Growth for 8 days with xylan instead of cellulose stimulated xylanase production by $T$. pullulans twofold but 
Table 5. Glucose and cellobiose produced during $24 h$ assay with ball-milled filter paper as substrate

Cultures were grown as in Table 3, and the cellulase preparations were incubated for $24 \mathrm{~h}$ at $37^{\circ} \mathrm{C}$ with ball-milled filter paper. Products were determined as described in Methods. Cellobiose was determined by subtracting results for glucose from those for glucose + cellobiose and multiplying by 0.95 to correct for water of hydration. Results are expressed in $\mu \mathrm{g}$ (ml filtrate) ${ }^{-1}$.

\section{Organism}

Trichosporon cutaneum YI

T. pullulans $\mathrm{C} 35$

Trichoderma viride CSI 2

Myrothecium verrucaria IMI4554I
Total soluble
carbohydrate

412

455

928

985

II 86

513

540
Glucose +
cellobiose

$$
368
$$

314

1000

882

1073

538

544

Glucose
26
24
141
158
670
260
198

Cellobiose

(by difference)

325
276
816
688
383
264
329

no effect was observed with $T$. cutaneum YI. The most active preparation from $T$. pullulans CBS2532 solubilized $42 \%$ of the xylan in $3 \mathrm{~h}$ and $55 \%$ in $24 \mathrm{~h}$.

\section{Effect of time on the rate of cellulolysis}

The most active cellulase preparations were tested, with dewaxed cotton yarn as substrate, in assays lasting for from $3 \mathrm{~h}$ to 7 days. On the basis of the specific activities obtained in $24 \mathrm{~h}$ incubations (Table 4), we anticipated that the rate of solubilization would decrease with time resulting in lower specific activities with longer assay times (Mandels \& Weber, 1969; Halliwell, 1961). The cellulases from Trichoderma viride and $T$. cutaneum showed the most constant rates, that from Trichoderma viride CSI 2 being constant for up to $24 \mathrm{~h}$ and that from $T$. cutaneum YI, after decreasing by $50 \%$ within the first $8 \mathrm{~h}$, remaining unchanged for up to 7 days. The rate of cellulolysis by T. pullulans $\mathrm{C} 35$ cellulase decreased by $55 \%$ during the first $8 \mathrm{~h}$ and showed a further $23 \%$ decrease between $24 \mathrm{~h}$ and 7 days. That from $M$. verrucaria showed an initial decrease of $75 \%$ during the first $6 \mathrm{~h}$ but then remained constant for at least a further $2 \mathrm{I} \mathrm{h}$, an effect also found by Halliwell (196I).

\section{Products of cellulose degradation}

Dennis (1972) found that glucose and cellobiose were the main reducing sugars produced by $T$. cutaneum Y I cellulase acting on ball-milled filter paper and on carboxymethylcellulose substrates. Examination by t.l.c. of filtrates from assays with ball-milled filter paper and dewaxed cotton yarn as substrates produced similar results and showed specific differences in the proportions of reducing sugars. Whereas strains of the yeasts $T$. cutaneum and T. pullulans produced mainly cellobiose and only a little glucose, the mould Trichoderma viride produced mainly glucose with small amounts of cellobiose and $M$. verrucaria produced glucose and cellobiose in approximately equal amounts. These patterns were independent of the type of cellulose substrate and time of incubation although the total amounts, as indicated by the intensity of the spots, varied. Traces of both cellotriose and cellotetraose (spots only visible under ultraviolet light) were produced by $T$. cutaneum and $T$. pullulans but $M$. verrucaria produced only cellotriose. Estimation of glucose and cellobiose in the assay filtrates generally confirmed the t.l.c. results, especially for assay times of $24 \mathrm{~h}$ or longer (Table 5) and accounted for most of the soluble carbohydrate. The results for cellobiose in Table 5 may include glucose degraded by $\beta$-glucosidase from any cellooligosaccharide present (Levinson, Mandels \& Reese, I95I). The results for T. pullulans 


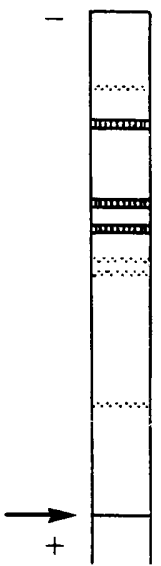

(a)

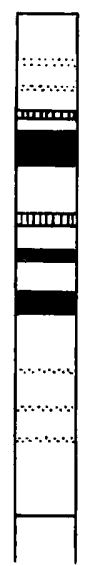

(b)

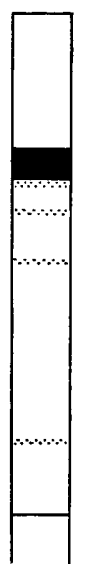

(c)

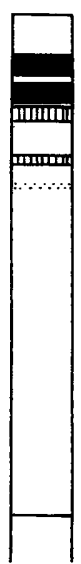

(d)

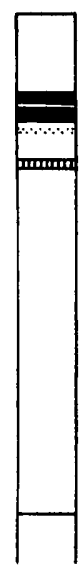

(e)

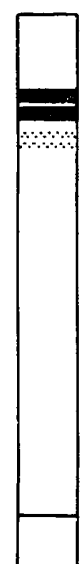

(f)

Fig. 2. Diagram of polyacrylamide gels after electrophoresis of culture filtrates. (a) Trichoderma viride CSI2; (b) Myrothecium verrucaria IMI4554I; (c) Trichosporon cutaneum YI; (d) T. pullulans C35; (e) $T$. pullulans CBS2532 (active); $(f) T$. pullulans CBS2532 (inactive). The density of the bands is indicated by the degree of shading; the arrow indicates the position of the bromophenol blue marker.

C35 were obtained from the most active filtrate (specific activity $18 \cdot 9$ ); the carbohydrate solubilized represents approximately $17 \%$ of the cellulose. Trichoderma viride CSI 2 cellulase produced a greater glucose:cellobiose ratio as the assay time increased: at $3 \mathrm{~h}$ with ballmilled filter paper as substrate, the ratio was approximately I $5: \mathrm{I}$; after $24 \mathrm{~h}$, with $\alpha$-cellulose also, it was $\mathrm{I} \cdot 7: \mathrm{I}$; and after 7 days with $\alpha$-cellulose, it had increased to I3: I.

\section{Products of xylan degradation}

Examination of xylan assay filtrates by t.l.c. showed that with yeast xylanase the main breakdown product was probably xylobiose with some xylotriose and traces of xylose. Glucose and possibly mannose were also present but their concentrations were too low to confirm by assay. The moulds produced similar products but with relatively more xylose which was the major product with Trichoderma viride.

The breakdown of the xylan present in some preparations of $\alpha$-cellulose followed a similar pattern although with xylanase from $T$. cutaneum G3I and $T$. pullulans CBS2532 xylobiose was only just detectable after 7 days whereas Trichoderma viride produced a considerable amount of xylose after $24 \mathrm{~h}$.

The presence of impurities in the xylan was evident from the considerable amount of soluble carbohydrate ( 30 to $35 \%$ ) observed in the assay controls although t.l.c. revealed only slow-moving compounds in trace amounts. A sample of xylan was partially purified (see Methods); after acid hydrolysis followed by t.l.c. most fractions contained glucose and mannose in addition to xylose but the acid-precipitated fraction from the $4 \% \mathrm{NaOH}$ extract contained mainly xylose with a small amount of glucose. This purified xylan was used as a substrate in $3 \mathrm{~h}$ assays with an enzyme preparation from $T$. pullulans $\mathrm{C}_{35}$ and gave an activity of 29 units ( $\mu \mathrm{g}$ protein $)^{-1}$. Comparison of this with the activity of 65 units $(\mu \mathrm{g}$ protein $)^{-1}$ measured using the unpurified xylan as substrate indicated the presence of other polymers, probably glucomannans, in the crude xylan. T.l.c. of the assay filtrates showed a similar breakdown pattern except for the absence of the trace of a slow-running unidentified compound $\left(R_{\mathrm{xyl}} 0.3 \mathrm{I}\right)$ from the purified xylan. 


\section{Proteins in culture filtrates}

Polyacrylamide gel electrophoresis of filtrates of yeast strains produced strain-specific patterns of three to five stained bands with similar electrophoretic mobilities (Fig. 2). Two of the bands appeared to be common to both $T$. cutaneum Y I and $T$. pullulans $\mathrm{C} 35$. The slower moving band was the major component from $T$. cutaneum YI. Trichoderma viride and $M$. verrucaria gave more complicated patterns with seven and at least ro bands respectively spread along the length of the gel. In some experiments cultures failed to show any cellulase activity. A filtrate from one of these cultures of $T$. pullulans CBS2532 was examined by polyacrylamide gel electrophoresis; it lacked one protein band which was present in two active filtrates (Fig. 2).

\section{DISCUSSION}

The present work was initiated to compare the cellulase activity produced by Trichosporon species with that produced by the moulds Trichoderma viride and $M$. verrucaria. Production of cellulase by $T$. cutaneum and $T$. pullulans was favoured by a high cell density although attempts to stimulate or induce earlier production were unsuccessful. Restriction of growth through sub-optimum conditions or by limitation of carbohydrate availability favours the production of mould cellulases (Hulme \& Stranks, 1971) and a high density of cells in the stationary phase of growth could be considered as fulfilling this condition. Growth at sub-optimum temperatures gave no appreciable increase in cellulase production by Trichosporon species. Limitation of growth by glucose starvation also failed to stimulate cellulase production although a transient low activity was observed and a high concentration of soluble protein was produced which was paralleled by carboxymethylcellulase activity (unpublished results). A similar phenomenon could have accounted for the effect shown in Fig. I where specific activity reached a maximum and then decreased slightly whereas soluble protein concentration continued to increase, indicating that protein other than cellulase was being produced. A similar effect has been observed with moulds (Wood, I968). Analysis of the soluble products formed from cellulose shows clear differences between the cellulase preparations from species of the genera Trichosporon, Trichoderma and Myrothecium. This probably reflects a different composition of the complex of enzymes required to produce glucose from cellulose, possibly in the $\beta$-glucosidase activity or in the exo-( $\rightarrow 4)-\beta$ glucanase activity of the $C_{x}$ component (King \& Vessal, 1969) as indicated by the proportions of cellobiose and glucose in the mixture of products. Examination by polyacrylamide gel electrophoresis also distinguished between the proteins present in the culture filtrates of species of Trichosporon, Trichoderma and Myrothecium. The fewer proteins produced by the yeasts may increase their commercial potential. No attempt has been made to determine the cellulase activity of individual proteins but the absence of one protein band from an inactive preparation of $T$. pullulans CBS2532 suggests that this protein is necessary for cellulase activity.

Our studies show that some strains of $T$. cutaneum and $T$. pullulans possess considerable xylanase activity, equal to, or greater than that produced by Trichoderma viride CSI 2 . The lower activity obtained with the purified xylan as substrate indicates that the culture filtrates are also active against glucomannan which may be present in some preparations of xylan. However, the ability of these yeasts to degrade xylan present in $\alpha$-cellulose was much lower, possibly because the cellulase from Trichoderma viride CSI 2 renders the xylan more accessible to attack. Nomura et al. (1968) have demonstrated xylanase activity in Trichoderma viride strains and Toda, Suzuki \& Nisizawa (1970, 197I) in other Trichoderma species. 
During the course of this work active preparations were difficult to obtain consistently; about one in three of the preparations had low activity and this was usually associated with low protein concentrations. Other workers have encountered variation in the activity and properties of $M$. verrucaria preparations obtained under apparently identical conditions (Halliwell, I961; Selby, Maitland \& Thompson, 1963). The cause of these variations has not been established.

Of the yeasts tested, the cellulase and xylanase activities of $T$. pullulans $\mathrm{C} 35$ were highest and were comparable to the activities and yields of these enzymes by Trichoderma viride CSI2. Trichosporon cutaneum XI, while producing a lower cellulase activity in the standard assay system, maintained the rate of cellulolysis over a longer time. The cellulase preparations from these two organisms therefore may have different applications. The synthesis of considerable cellulase and xylanase activities by these yeast species enables the preparation of culture filtrates with potentially high macerating power.

We are grateful to Drs J. L. Peel and W. M. Waites for critical reading of the manuscript, Dr R. R. Selvendran for paper chromatographic analysis of the cellulose hydrolysates and to J. E. T. Gooch for skilled technical assistance.

\section{REFERENCES}

Aspinall, G. O. \& McKay, J. E. (1958). The hemicelluloses of European larch (Larix decidua). Part I. The constitution of a xylan. Journal of the Chemical Society, 1059-1066.

BarnetT, J. A. \& INGRAM, M. (I955). Technique in the study of yeast assimilation reactions. Journal of Applied Bacteriology 18, 13 I-148.

Bishop, C. T. \& WhitAKER, D. R. (I955). Mixed arabinose-xylose oligosaccharides from wheat-straw xylan. Chemistry and Industry, I 19.

Bravery, A. F. (1968). Microbiological breakdown of cellulose in the presence of alternative carbon sources. Journal of the Science of Food and Agriculture 19, 133-1 35.

BRown, W. (1970). The separation of cellodextrins by gel permeation chromatography. Journal of Chromatography 52, 273-284.

DAvis, B. J. \& ORNSTEIN, L. (196I). Disc Electrophoresis. Rochester, U.S.A.: Distillation Products Industries.

DENNIS, C. (1972). Breakdown of cellulose by yeast species. Journal of General Microbiology 7X, 409-4I I.

DENNIS, C. \& GEE, J. M. (1973). The microbial flora of broiler-house litter and dust. Journal of General Microbiology 78, 10I-107.

Evans, C. G. T., Herbert, D. \& Tempest, D. W. (1970). Continuous cultivation of micro-organisms. 2. Construction of a chemostat. In Methods in Microbiology, vol. 2, pp. 277-323. Edited by J. R. Norris and D. W. Ribbons. London: Academic Press.

FrahN, J. L. \& Mills, J. A. (1959). Paper ionophoresis of carbohydrates. I. Procedures and results for four electrolytes. Australian Journal of Chemistry 12, 65-89.

Gascoigne, J. A. \& Gascoigne, M. M. (1960). The xylanases of Fusarium roseum. Journal of General Microbiology 22, 242-248.

Halliwell, G. (I957). Cellulolysis by rumen micro-organisms. Journal of General Microbiology I7, I53-I65.

Halliwell, G. (1960). A micro-determination of carbohydrates and proteins. Biochemical Journal 74, 457-462.

Halliwell, G. (I96I). The action of cellulolytic enzymes from Myrothecium verrucaria. Biochemical Journal 79, $185-192$.

Hulme, M. A. \& Stranks, D. W. (I97I). Regulation of cellulase production by Myrothecium verrucaria grown on non-cellulosic substrates. Journal of General Microbiology 69, I45-1 55.

King, K. W. \& VesSAL, M. I. (I969). Enzymes of the cellulase complex. In Cellulases and their Applications, Advances in Chemistry Series no. 95, pp. 7-25. Edited by R. F. Gould. Washington: American Chemical Society.

Levinson, H. S., Mandels, G. R. \& Reese, E. T. (I95I). Products of enzymatic hydrolysis of cellulose and its derivatives. Archives of Biochemistry and Biophysics 31, 35 I-365.

Lowry, O. H., Rosebrough, N. J., FarR, A. L. \& Randall, R. J. (I95I). Protein measurement with the Folin phenol reagent. Journal of Biological Chemistry I93, 265-275.

Mandels, M. \& Weber, J. (I969). The production of cellulases. In Cellulases and their Applications, Advances in Chemistry Series no. 95, pp. 39I-413. Edited by R. F. Gould. Washington: American Chemical Society. 
Mandels, M., Weber, J. \& PARizeK, R. (197I). Enhanced cellulase production by a mutant of Trichoderma viride. Applied Microbiology 21, I52-I54.

Miller, G. L. (1963). Cellodextrins. In Methods of Carbohydrate Chemistry, vol. III, pp. 134-139. Edited by R. L. Whistler. London: Academic Press.

Nomura, K., Yasui, T., Kiyooka, S. \& Kobayashi, T. (1968). Xylanases of Trichoderma viride. Some properties of enzyme reaction and a preliminary experiment of xylan hydrolysis. Journal of Fermentation Technology 46, 634-640.

Partridge, S. M. (1949). Aniline hydrogen phthalate as a spraying reagent for chromatography of sugars. Nature, London 164, 443.

Pathak, A. N. \& Ghose, T. K. (I973a). Cellulases-I: sources, technology. Process Biochemistry 8(4), $35-38$.

Pathak, A. N. \& Ghose, T. K. (1973b). Cellulases-2: applications. Process Biochemistry 8(5), $20-21$.

REese, E. T., SiU, R. G. H. \& Levinson, H. S. (1950). The biological degradation of soluble cellulose derivatives and its relationship to the mechanism of cellulose hydrolysis. Journal of Bacteriology 59, 485-497.

Selby, K. (1967). The cellulase of Trichoderma viride. Separation of the components involved in the solubilisation of cotton. Biochemical Journal ro4, 716-724.

Selby, K., Maitland, C. C. \& Thompson, K. V. A. (I963). The degradation of cotton cellulose by the extracellular cellulase of Myrothecium verrucaria. 2. The existence of an 'exhaustible' cellulase. Biochemical Journal 88, 288-296.

Toda, S., SUzUKI, H. \& NisizAWA, K. (1970). Isolation of cellulase components with xylanase activity. Hakko Kogaku Zasshi 48, 580-586.

Toda, S., Suzuki, H. \& Nisizawa, K. (I97I). Enzymatic properties and the substrate specificities of Trichoderma cellulases with special reference to their activity towards xylan. Hakko Kogaku Zasshi 49, 499-52I.

Toyama, N. (1969). Applications of cellulases in Japan. In Cellulases and their Applications, Advances in Chemistry Series no. 95, pp. 359-390. Edited by R. F. Gould. Washington: American Chemical Society.

WALSH, J. H. \& STEWART, C. S. (I97I). Effect of temperature, oxygen and carbon dioxide on cellulolytic activity of some fungi. Transactions of the British Mycological Society 57, 75-84.

WiCKerham, L. J. \& Burton, K. A. (I948). Carbon assimilation tests for the classification of yeasts. Journal of Bacteriology 56, 363-37I.

Wood, T. M. (1968). Cellulolytic enzyme system of Trichoderma koningii: separation of components attacking native cotton. Biochemical Journal rog, $217-227$.

Wood, T. M. \& PhILliPs, D. R. (1969). Another source of cellulase. Nature, London 222, 986-987. 